\title{
Association of gene BoLA DRB3.2 with production traits in a dairy herd of Antioquia, Colombia
}

\section{Asociación del gen BoLA DRB3.2 con características productivas en un hato lechero de Antioquia, Colombia}

\author{
Juan Zambrano A, ${ }^{1}$ M.Sc, Julián Echeverri Z, ${ }^{2}$ Ph.D, Albeiro López-Herrera, ${ }^{3 *}$ Ph.D.
}

\begin{abstract}
${ }^{1}$ Universidad Nacional de Colombia sede Medellín, Facultad de Ciencias, Posgrado en Biotecnología, Grupo de Investigación BIOGEM. ${ }^{2}$ Universidad Nacional de Colombia, Sede Medellín, Facultad de Ciencias Agropecuarias, Departamento de Producción Animal, Grupo de Investigación BIOGEM. ${ }^{3}$ Universidad Nacional de Colombia Sede Medellín, Facultad de Ciencias Agropecuarias, Departamento de Producción Animal, grupo de Investigación BIOGEM, Calle 59A No 63-20 -Núcleo el volador, Bloque 50, Oficina 310, Medellín Colombia. *Correspondencia: alherrera@unalmed.edu.co
\end{abstract}

Received: January 2013; Accepted:December 2013.

\begin{abstract}
Objective. To determine the associations of BoLA DRB3.2 alleles present in Holstein and BON $x$ Holstein cattle to production and milk quality traits in a dairy herd of Antioquia, Colombia. Materials and methods. Ninety-one cows, 66 Holstein and $25 \mathrm{BxH}$, were genotyped for the BoLA DRB3.2 gene, through PCR-RFLP technique. Furthermore, the association of the alleles of the gene BoLA DRB3.2 with milk yield (PL305), fat yield (PG305), protein yield (PP305) fat percentage (PGRA) and protein percentage (PPRO) were determined, using a general linear model. Results. Twenty-seven BoLA DRB3.2 alleles were identified; the most frequent alleles in Holstein were: BoLA DRB3.2*23, 22 , and 24 with frequencies of: $0.159,0.129$, and 0.106 , respectively and the most frequent alleles in BxH were: BoLA DRB3.2*23, 24 and 20 with frequencies of: $0.20,0.140$, and 0.120 , respectively. Associations of BoLA DRB3.2 alleles with production and milk quality traits were also determined. In Holstein cows the BoLA DRB3.2*36 allele was associated with low PL305 ( $\leq \leq 0.01)$, high PGRA in multiparous cows $(p \leq 0.05)$ and high PG305 in primiparous cows $(p \leq 0.01)$. The BoLA DRB3.2*33 allele was associated with increased in the PPRO in multiparous cows $(p \leq 0.01)$. In $B X H$ cows only the BoLA DRB3*19 allele was associated with high PGRA $(p \leq 0.05)$. Conclusions. The gene BoLA DRB3.2 shows high polymorphism in both groups; Holstein and $\mathrm{BxH}$ and some of its allelic variants were associated with production and milk quality traits.
\end{abstract}

Key words: DNA, genetic markers, milk protein, PCR (Source:CAB, AIMS). 


\section{RESUMEN}

Objetivo. Determinar la asociación de los alelos BoLA DRB3.2 presentes en vacas Holstein y BONxHolstein con características productivas y de calidad composicional de la leche en un hato lechero de Antioquia, Colombia. Materiales y métodos. Fueron genotipificados 91 animales; 66 Holstein y 25 BONxHolstein (BxH) para el gen BoLA DRB3.2, mediante la técnica PCR-RFLP. También, se determinó la asociación de los alelos del gen BoLA DRB3.2 con producción de leche (PL305), producción de grasa (PG305), producción de proteína (PP305), porcentaje de grasa (PGRA) y porcentaje de proteína (PPRO); usando un modelo lineal generalizado. Resultados. Fueron identificados 27 alelos BoLA DRB3.2; los más frecuentes en Holstein fueron: BoLA DRB3.2*23, 22 y 24 con frecuencias de $0.159,0.129$ y 0.106 respectivamente y los más frecuentes para BxH fueron: BoLA DRB3.2*23, 24, 20 con frecuencias de $0.20,0.140$ y 0.120 respectivamente. También fueron determinadas asociaciones de los alelos BoLA DRB3.2 con características productivas y de calidad composicional de la leche. En vacas Holstein el alelo BoLA DRB3.2*36 fue asociado con baja PL305 ( $p \leq 0.01)$, alto PGRA en vacas multíparas $(p \leq 0.05)$ y alta PG305 en vacas primíparas $(p \leq 0.01)$. El alelo BoLA DRB3.2*33 fue asociado con alto PPRO en vacas multíparas $(p \leq 0.01)$. En vacas $B \times H$ sólo el alelo BoLA DRB3.2*19 estuvo asociado con aumento en el PGRA $(p \leq 0.05)$. Conclusiones. El gen BoLA DRB3.2 presentó un alto polimorfismo en ambos grupos genéticos; Holstein y $\mathrm{BxH}$ y algunas de sus variantes alélicas fueron asociadas significativamente con características productivas y características de calidad composicional de la leche.

Palabras clave: DNA, marcadores genéticos, PCR, proteína de la leche (Fuente: CAB, AIMS).

\section{INTRODUCTION}

Milk production in Colombia has increased in an accelerated and sustained manner. In the year 1990, raw milk production was 3917 million liters, by the year 2012 , it increased by $40 \%$; reaching a production of 6518 million liters $(1,2)$. This growth over the last 20 years shows not just the growth in number of animals, but also the use of bulls selected for their high genetic value for dairy production.

However, the intense selection of productive characteristics has led to an increase in the appearance of infectious diseases, metabolic problems, and diminished fertility in cattle (3). The costs associated to these types of problems, are mainly represented by the decrease in milk production, veterinary costs, premature discard of animals, milk rejection due to antibiotic contamination, among others (4).

There have been few and isolated intents in Colombia, to know the genetic value (genetic evaluations) of dairy cows and Bulls, and they have been undertaken, mainly to estimate volume of milk (5). Cattle ranchers, on their part, have aimed their production mainly towards milk volume, rather than towards quality, regarding composition and sanitary condition. Thus, strategies are required to allow improvement of production, milk quality, and cattle health.

Genetic improvement assisted by molecular markers is one of the alternatives that allows for the study of genes associated to productivity, milk

\section{INTRODUCCION}

La producción de leche en Colombia se ha incrementado de forma acelerada y sostenida. En el año 1990, la producción de leche cruda fue de 3917 millones de litros, al año 2012 se incrementó en $40 \%$; llegando a una producción de 6518 millones de litros $(1,2)$. Este crecimiento en los últimos 20 años, refleja no sólo el crecimiento en el número de animales, sino también el uso de toros que han sido seleccionados por su alto valor genético para volumen de producción de leche.

Sin embargo, la intensa selección para características productivas ha conllevado al incremento en la incidencia de enfermedades infecciosas, problemas metabólicos y disminución de la fertilidad de las vacas (3). Los costos asociados con este tipo de problemas están representados principalmente en la disminución de la producción de leche, gastos veterinarios, descarte prematuro de animales, descarte de leche por contaminación con antibióticos, entre otros (4).

En Colombia han sido pocos y aislados los intentos por conocer el valor genético (evaluaciones genéticas) de vacas y toros lecheros y han sido estimados principalmente para volumen de producción (5). Los ganaderos, por su parte, han dirigido sus explotaciones principalmente hacia la producción de leche más que a su calidad composicional y/o sanitaria. Por tanto, se requiere plantear estrategias que permitan mejorar además de la producción, la calidad de la leche y la salud de la vaca. 
quality and also to resistance or vulnerability to infectious diseases. The major histocompatibility complex (MHC), which in bovines is called Bovine Leucocyte Antigen (BoLA), has been widely studied, and some molecular markers associated to production, compositional quality of milk and sanitary problems have been identified, such as gene BoLA DRB3 (6).

Gene BoLA DRB3, is usually expressed by cells in the immune system such as macrophages dendritic cells or B lymphocytes, which process the antigen and then present it to the helper $\mathrm{T}$ lymphocytes to unleash the immune response against infectious pathogens(7). Their elevated level of expression and high polymorphism makes them potential molecular markers for Molecular Marker-assisted selection procedures (MAS). More than 100 different alleles $(8,9)$ have been identified from exon 2, and some of them have been associated to the occurrence of infectious diseases and milk, fat and protein production $(6,10-13)$.

The purpose of this investigation was to determine the association of the alleles of BoLA DRB3.2 gene with milk production and compositional quality traits in Holstein and BON $x$ Holstein cattle, at a dairy farm in Antioquia, Colombia.

\section{MATERIALS AND METHODS}

Population of the study. The investigation was undertaken at the Paysandú farm, which is property of the Universidad Nacional de Colombia, Medellin branch, located in the department of Antioquia, Township of Santa Elena, $16 \mathrm{~km}$ east of Medellín in an area of lower montane rain forest (bmh-MB) with a mean temperature of $14^{\circ} \mathrm{C}$ at 2500 meters above sea level. 91 bovine females were genotipified at this farm for gene BoLA DRB3.2, 66 of them were Holstein and 25 were from the $\mathrm{BxH}$ genetic group.

Data recollection. Data of milk yield per lactation was gathered from the historical production data of the Paysandú farm and adjusted to 305 days (PL305). Milk production was measures with proportional flow meters. The characteristics of compositional quality of the milk were: fat percentage (PGRA) and protein percentage (PPRO), they were determined at the quality control lab of COLANTA, using the MilkoScan FT $120^{\circledR}$ device, based on the FTIR principle (Fourier Transfer Infrared Spectroscopy).

Cows with different number of lactations were taken for this study (between one and eleven).
El mejoramiento genético asistido por marcadores moleculares, es una de las alternativas que permite estudiar genes asociados con productividad, calidad de la leche y también con resistencia y/o susceptibilidad a enfermedades infecciosas. El complejo mayor de histocompatibilidad $(\mathrm{CMH})$, que en bovinos se denomina antígeno Leucocitario Bovino (BoLA), ha sido ampliamente estudiado y han sido identificados algunos marcadores moleculares asociados a producción, calidad composicional de la leche y también con problemas sanitarios como es el caso del gen BoLA DRB3 (6).

El gen BoLA DRB3, es normalmente expresado por células del sistema inmune como macrófagos, células dendríticas y linfocitos $B$, las cuales procesan el antígeno y luego lo presentan a los linfocitos $\mathrm{T}$ ayudadores para desencadenar la respuesta inmune contra patógenos infecciosos (7). Su nivel de expresión elevado y su alto polimorfismo lo convierte en un marcador molecular potencial para programas de selección asistida por marcadores moleculares (MAS). Del exón 2 de este gen han sido identificados más de 100 alelos diferentes $(8,9)$ y algunos de estos han sido asociados con ocurrencia a enfermedades infecciosas, producción de leche, grasa y proteína (6,10-13).

El objetivo de esta investigación fue determinar la asociación de los alelos del gen BoLA DRB3.2 con características productivas y de calidad composicional de la leche en vacas Holstein y BONxHolstein en un hato lechero de Antioquia, Colombia.

\section{MATERIALES Y METODOS}

Población de estudio. La investigación se llevó a cabo en el hato Paysandú de propiedad de la Universidad Nacional de Colombia sede Medellín, ubicado en el departamento de Antioquia, corregimiento de Santa Elena, a $16 \mathrm{Km}$ al oriente de Medellín en zona de bosque muy húmedo montano bajo (bmh-MB) con una temperatura media de $14^{\circ} \mathrm{C}$ y a una altura de $2500 \mathrm{msnm}$. En este hato fueron genotipificadas 91 hembras bovinas para el gen BoLA DRB3.2, 66 de raza Holstein y 25 del grupo genético $\mathrm{BxH}$.

Recolección de la información. Los datos de producción de leche por lactancia fueron tomados de los registros históricos de producción del hato Paysandú y fueron ajustados a 305 días (PL305). La producción de leche fue medida con medidores de paso proporcional. Las características de calidad composicional de la leche: porcentaje de grasa (PGRA) y porcentaje de proteína (PPRO), 
For PGRA and PPRO cows with less than four data per lactation were included. Fat yield (PG305) and protein yield (PP305) in kg/lactation adjusted to 305 days was calculated as of the percentage of these parameters (PPRO y PGRA) and the milk yield adjusted to 305 days (PL305).

DNA extraction. $5 \mathrm{ml}$ of peripheric blood was drawn into vacuum tubes with EDTA as anticoagulant, from each one of the 91 individuals. They were stored at $4^{\circ} \mathrm{C}$ until processed. DNA was extracted through the "salting out" method.

Amplification of the BoLA DRB3.2. gene. Exon 2 of gene BoLA DRB3 was amplified by semi-nested PCR, described by Van Eijk et al (14), with a few modifications. The primers used were: HL030 (ATCCTCTCTCTGCAGCACATTTCC), HL031 (TTTAAATTCGCG CTCACCTCGCCGCT) and HL032 (TCGCCGCTGCACAGTGAAACTCTC). The first amplification cycle was done at a reaction volume of $25 \mu$ containing: $0.4 \mathrm{mM}$ of each dNTP, $0.5 \mu \mathrm{M}$ primer HLO30 and HLO31, $2.5 \mu \mathrm{l} \mathrm{10X}$ magnesium free thermophilic buffer $[500 \mathrm{mM}$ $\mathrm{KCl}, 100 \mathrm{mM}$ Tris- $\mathrm{HCl}(\mathrm{pH} 9.0), 1 \%(\mathrm{v} / \mathrm{v})$ Triton $\mathrm{X}-100 \& \# 093,2.5 \mu \mathrm{l}$ of $25 \mathrm{mM} \mathrm{MgCl}, 12.8 \mu \mathrm{l}$ of ultra-pure water, $1 U$ Taq DNA polymerase (Fermentas, California, U.S.A) and 50 to 100 $\mathrm{ng}$ of genomic DNA. The reaction mixture took place in a thermo cycler (Biometra, Göttingen Germany with the following temperature program: Initial denaturation at $94^{\circ} \mathrm{C}$ for $240 \mathrm{~s}$, followed by 10 denaturation cycles at $94^{\circ} \mathrm{C}$ for 60 $\mathrm{s}$, annealing at $60^{\circ} \mathrm{C}$ for $120 \mathrm{~s}$, extension at $72^{\circ} \mathrm{C}$ for $60 \mathrm{~s}$ and a final extension at $72^{\circ} \mathrm{C}$ for $300 \mathrm{~s}$.

The second PCR cycle was done at a reaction volume of $60 \mu$ containing: $0.4 \mathrm{mM}$ of each dNTP, $0.6 \mu \mathrm{M}$ of each primer HLO30 and HLO32, $6 \mu \mathrm{l}$ of $10 \mathrm{X}$ magnesium-free thermophilic buffer, $6 \mu \mathrm{l}$ of $25 \mathrm{mM} \mathrm{MgCl}, 36.9 \mu \mathrm{l}$ of ultra pure water, $1 \mathrm{U}$ of Taq ADN polymerase (Fermentas, California, U.S.A) and $2.5 \mu \mathrm{l}$ of amplified DNA from the first PCR cycle. The amplification program was as follows: Initial denaturation at $94^{\circ} \mathrm{C}$ for $240 \mathrm{~s}$, followed by 25 denaturation cycles at $94^{\circ} \mathrm{C}$ for $60 \mathrm{~s}$, annealing at $67^{\circ} \mathrm{C}$ for $120 \mathrm{~s}$, extension at $72^{\circ} \mathrm{C}$ for $60 \mathrm{~s}$, followed by a final extension of $72^{\circ} \mathrm{C}$ for $300 \mathrm{~s}$. As negative control, reactions were undertaken without DNA. The resulting product was fixed in agarose gels at $1.5 \%(\mathrm{p} / \mathrm{v})$ and visualized under ultraviolet light with a trans illuminator. (Biometra, Göttingen Germany).

Digestion with restriction enzymes. The amplification product obtained during the second PCR cycle was digested with three restriction enzymes RsaI, BstYI (New England BioLabs $^{\circledR}$ ) and HaeIII (Fermentas, California se determinaron en el laboratorio de control de calidad de la Cooperativa COLANTA, usando el equipo MilkoScan $\mathrm{FT} 120^{\circledR}$, basado en el principio de medición FTIR (infrarrojo por transformada de Fourier).

En esta investigación se incluyeron vacas con diferente número de lactancias (entre una y once). Para PGRA y PPRO fueron incluidas vacas que tenían al menos cuatro mediciones por cada lactancia. La producción de grasa (PG305) y producción de proteína (PP305) en kg/lactancia ajustado a 305 días, fue calculada a partir del porcentaje de estos parámetros (PPRO y PGRA) y de la producción leche ajustada a 305 días (PL305).

Extracción de ADN. Para cada uno de los 91 individuos se colectaron $5 \mathrm{ml}$ de sangre periférica en tubos al vacío con EDTA como anticoagulante y fueron almacenadas a $4^{\circ} \mathrm{C}$ hasta su procesamiento. EI ADN fue extraído empleando el método de "salting out".

Amplificación del gen BoLA DRB3.2. EI exón 2 del gen BoLA DRB3 fue amplificado por PCR semianidada, como lo describe Van Eijk et al (14), con algunas modificaciones. Los cebadores utilizados fueron: HL030 (ATCCTCTCTCTGCAGCACATTTCC), HL031 (TTTAAATTCGCG CTCACCTCGCCGCT) y HL032 (TCGCCGCTGCACAGTGAAACTCTC). La primera ronda de amplificación se realizó en un volumen de reacción de $25 \mu \mathrm{l}$ que contenía: $0.4 \mathrm{mM}$ de cada dNTP, $0.5 \mu \mathrm{M}$ de cebadores HLO30 y HLO31, $2.5 \mu l$ de 10X tampón termofílico libre de magnesio [500 mM KCl, $100 \mathrm{mM}$ Tris- $\mathrm{HCl}(\mathrm{pH}$ 9.0), 1\% (v/v) Tritón X-100\&\#093, $2.5 \mu \mathrm{l}$ of 25 $\mathrm{mM} \mathrm{MgCl} 2,12.8 \mu \mathrm{l}$ de agua ultrapura, $1 \mathrm{U}$ de Taq ADN polimerasa (Fermentas, California, U.S.A) y 50 a $100 \mathrm{ng}$ de ADN genómico. La mezcla de reacción se llevó a cabo en un termociclador (Biometra, Göttingen Germany con el siguiente programa de temperaturas: Desnaturalización inicial a $94^{\circ} \mathrm{C}$ por $240 \mathrm{~s}$, seguido de 10 ciclos desnaturalización a $94^{\circ} \mathrm{C}$ por $60 \mathrm{~s}$, alineación a $60^{\circ} \mathrm{C}$ por $120 \mathrm{~s}$, extensión a $72^{\circ} \mathrm{C}$ por $60 \mathrm{~s}$ y una extensión final a $72^{\circ} \mathrm{C}$ por $300 \mathrm{~s}$.

La segunda ronda de PCR se llevó a cabo en un volumen de reacción de $60 \mu$ que contenía: $0.4 \mathrm{mM}$ de cada dNTP, $0.6 \mu \mathrm{M}$ de cada cebador HLO30 y HLO32, $6 \mu$ le $10 X$ magnesium-free thermophilic tampón, $6 \mu \mathrm{l}$ de $25 \mathrm{mM} \mathrm{MgCl}_{2}$, $36.9 \mu \mathrm{l}$ de agua ultra pura, $1 \mathrm{U}$ de Taq ADN polimerasa (Fermentas, California, U.S.A) y $2.5 \mu \mathrm{l}$ de ADN amplificado en la primer ronda de PCR. El programa de amplificación fue el siguiente: Desnaturalización inicial a $94^{\circ} \mathrm{C}$ por 240 s, seguida de 25 ciclos desnaturalización 
U.S.A) and separation of fragments was done by electrophoresis in agarose gel. Identification of the alleles of BoLA DRB3.2 was done by combination of the different patterns of restriction obtained in the following order: RsaI, BstYI, HaeIII for each sample, according to the allele nomenclature reported by Van Eijk et al (14). The identified BoLA DRB3.2 alleles for PCR-RFLP, were confirmed by sequencing, for which our amplifiers in the second PCR cycle were purified with the QIAquick kit (QIAGEN) and sent to Macrogene Inc in Seoul Korea for sample sequencing. The sequences obtained were aligned and analyzed with the BioEdit Sequence Alignment Editor program.

Determination of allelic frequencies. The frequency of the different alleles was done by determining the proportion of each form of the gene between the total numbers of copies of the studied population. The homozygotes (two copies of the same allele) and heterozygotes (one copy of each allele) were identified and the frequency for each allele was calculated by counting the homozygotes and adding half of the heterozygotes, with the method described by Laird and Lange (15).

Statistical analysis. An allele substitution model was used to determine the association of each BoLA DRB3.2 allele with the productive and milk quality traits, using the BoLA DRB3.2*24 substitution allele, according to what was described by Sharif et al (10) and Rupp et al (11). The model was described as follows:

$Y_{i j k l}=\mu+G_{i}+N P_{j}+\Sigma_{k} b_{k} B O L A_{i j k}+e_{i j k l}$

Where: $Y_{\text {ijkl }}$ corresponds to the phenotype trait (PL305, PP305, PG305, PGRA and PPRO), $\mu$ is the general mean, GG corresponds to the $\mathrm{i}$ effect of the genetic group $(i=1,2)$, being 1 the Holstein genetic group and 2 the $\mathrm{BxH}$ genetic group, NP is the fixed effect of the $j$ number of calvings $(j=1,2)$, being 1 the primiparous cows (of one and two calvings) and 2 multiparous cows (of three or more calvings), $b_{k}$ is the regression coefficient of the number of copies of the $k$ allele BoLA, BoLA ${ }_{i j k}$ corresponds to the fixed effect of the number of copies $(0,1$ and 2$)$ of the BoLA $k$ $(k=1 \ldots . .15)$ allele present in cow $i j k$ and $e_{i j k l}$ is the experimental error.

Dunnett's comparison test was used to determine statistical significance between the means of the BoLA DRB3.2 alleles compared with the mean of the substitution allele (allele 24) for each productive trait. The comparison analysis in the Holstein breed was done by comparing means of each one of the groups: primiparous and a $94^{\circ} \mathrm{C}$ por $60 \mathrm{~s}$, alineación a $67^{\circ} \mathrm{C}$ por $120 \mathrm{~s}$, extensión a $72^{\circ} \mathrm{C}$ por $60 \mathrm{~s}$, seguido por una extensión final de $72^{\circ} \mathrm{C}$ por $300 \mathrm{~s}$. Como control negativo se hicieron reacciones en ausencia de ADN. El producto de PCR fue resuelto en geles de agarosa al $1.5 \%$ ( $p / v)$ y visualizado bajo luz ultravioleta en un fotodocumentador (Biometra, Göttingen Germany).

Digestión con enzimas de restricción. El amplificado obtenido en la segunda ronda de PCR fue digerido con tres enzimas de restricción RsaI, BstYI (New England BioLabs ${ }^{\circledR}$ ) y HaeIII (Fermentas, California U.S.A) y la separación de los fragmentos se realizó por electroforesis en gel de Agarosa. La identificación de los alelos del gen BoLA DRB3.2 se realizó por combinación de los diferentes patrones de restricción obtenidos en el siguiente orden: RsaI, BstYI, HaeIII para cada muestra de acuerdo a la nomenclatura alélica reportada por Van Eijk et al (14). Los alelos BoLA DRB3.2 identificados por PCR-RFLP, fueron confirmados por secuenciación, para lo cual las muestras amplificadas en la segunda ronda de PCR fueron purificadas con el kit QIAquick (QIAGEN) y enviadas a la empresa Macrogene Inc en Seúl Corea para realizar secuenciación de las muestras. Las secuencias obtenidas fueron alineadas y analizadas en el programa BioEdit Sequence Alignment Editor.

Determinación de frecuencias alélicas. La frecuencia de los diferentes alelos se realizó determinando la proporción de cada forma del gen entre el número de copias totales de la población en estudio. Se identificaron los homocigotos (dos copias del mismo alelo) y los heterocigotos (una copia de cada alelo) y se calculó la frecuencia de cada alelo contando los homocigotos y añadiendo la mitad de los heterocigotos, con el método descrito por Laird y Lange (15).

Análisis estadístico. Para determinar la asociación de cada alelo BoLA DRB3.2 con características productivas y de calidad de la leche se empleó un modelo de sustitución alélica, utilizando el alelo BoLA DRB3.2*24 como alelo de sustitución, según lo descrito por Sharif et al (10) y Rupp et al (11). El modelo fue descrito como:

$Y_{i j k l}=\mu+G G_{i}+N P_{j}+\Sigma_{k} b_{k} B o L A_{i j k}+e_{i j k l}$

Donde: $Y_{i j k l}$ corresponde a la característica fenotípica ('PL305, PP305, PG305, PGRA y PPRO), $\mu$ es la media general, GG corresponde al efecto fijo del i-ésimo grupo genético $(i=1,2)$, siendo 1 el grupo genético Holstein y 2 el grupo genético $\mathrm{BxH}, \mathrm{NP}$ es el efecto fijo del j-ésimo número de parto $(j=1,2)$, siendo 1 las vacas primíparas 
multiparous, independently for all the evaluated traits. For $\mathrm{BxH}$ the analysis was done in all the cows, due to the low number of animals $(n=25)$ for all the evaluated traits. Alleles with frequency $\leq 2 \%$ were grouped in one category named "others". The model was undertaken with the GLM (General Linear Model) procedure of SAS V9.1 (16).

\section{RESULTS}

Allele Frequencies for gene BoLA DRB3.2. 23 alleles from the Holstein breed, and 18 alleles from the $\mathrm{BxH}$ genetic group were identified through PCR-RFLP 23 for a total of 27 allele variants of BoLA DRB3.2. The allelic frequencies for the Holstein group were located between 0.008 and 0.159 (light grey bars Figure 1 ), being the most frequent alleles 23,22 and 24 with frequencies of $0.159,0.129$ y 0.106 , respectively. In $\mathrm{BxH}$ the allele frequencies were between 0.02 and 0.20 (dark bars Figure 1), being 23, 24 and 20 the most frequent alleles with frequencies of $0.20,0.14$ and 0.12 , respectively. It was determined that in the Holstein genetic group, $79 \%$ of the cows were heterozygote and $21 \%$ homozygote, for $\mathrm{BxH}$ a very similar result was obtained where $80 \%$ were heterozygote and $20 \%$ homozygote for gene BoLA DRB3.2.

Milk Production. The average PL305 in the evaluated population was $5361 \mathrm{Kg}$ (Table 1). The genetic group had a significant effect $(p \leq 0.01)$, with a PL305 mean higher for Holstein $(5895 \mathrm{~kg})$, than for BxH $(4045 \mathrm{~kg})$. Likewise, the calving effect was significant $(p \leq 0.01)$; primiparous Holstein cows presented a PL305 mean of $5316 \mathrm{~kg}$, while the mean for multiparous was $6599 \mathrm{~kg}$ per lactation (Table 1).

Protein production and percentage. The mean for PP305 was $162 \mathrm{~kg}$. The effect of the (de uno y dos partos) y 2 las vacas multíparas (de tres o más partos), $b_{k}$ es el coeficiente de regresión del número de copias del k-ésimo alelo BoLA, BoLA ${ }_{i j k}$ corresponde al efecto fijo del número de copias $(0,1$ y 2$)$ del alelo BoLA $k$ $(k=1 \ldots . .15)$ presentes en la vaca $i j k$ y $e_{i j k l}$ es el error experimental.

Para determinar la significancia estadística entre las medias de los alelos BoLA DRB3.2 comparadas con la media del alelo de sustitución (alelo 24) para cada característica productiva, se empleó la prueba de comparación de Dunnett's. Para la raza Holstein, se realizó el análisis de comparación de medias en cada uno de los grupos: primíparas y multíparas, de manera independiente en todas las características evaluadas. Para $\mathrm{BxH}$ el análisis se realizó en todas las vacas, por el bajo número de animales $(n=25)$ en todas las características evaluadas. Los alelos con frecuencias $\leq 2 \%$ fueron agrupados en una sola categoría denominada "otros". El modelo fue ejecutado con el procedimiento GLM (Modelo Lineal General) de SAS V9.1 (16).

\section{RESULTADOS}

Frecuencias alélicas para el gen BoLA DRB3.2. Fueron identificados por PCR-RFLP 23 alelos en la raza Holstein y 18 alelos en el grupo genético $\mathrm{BxH}$, para un total de 27 variantes alélicas del BoLA DRB3.2. Las frecuencias alélicas para la raza Holstein se ubicaron entre 0.008 y 0.159 (barras gris claro Figura 1 ), siendo los alelos más frecuentes el 23,22 y 24 con frecuencias de $0.159,0.129$ y 0.106 , respectivamente. En BxH las frecuencias alélicas estuvieron entre 0.02 y 0.20 (barras oscuras Figura 1), siendo los alelos más frecuentes el 23, 24 y 20 con frecuencias de $0.20,0.14$ y 0.12 , respectivamente. En el grupo genético Holstein

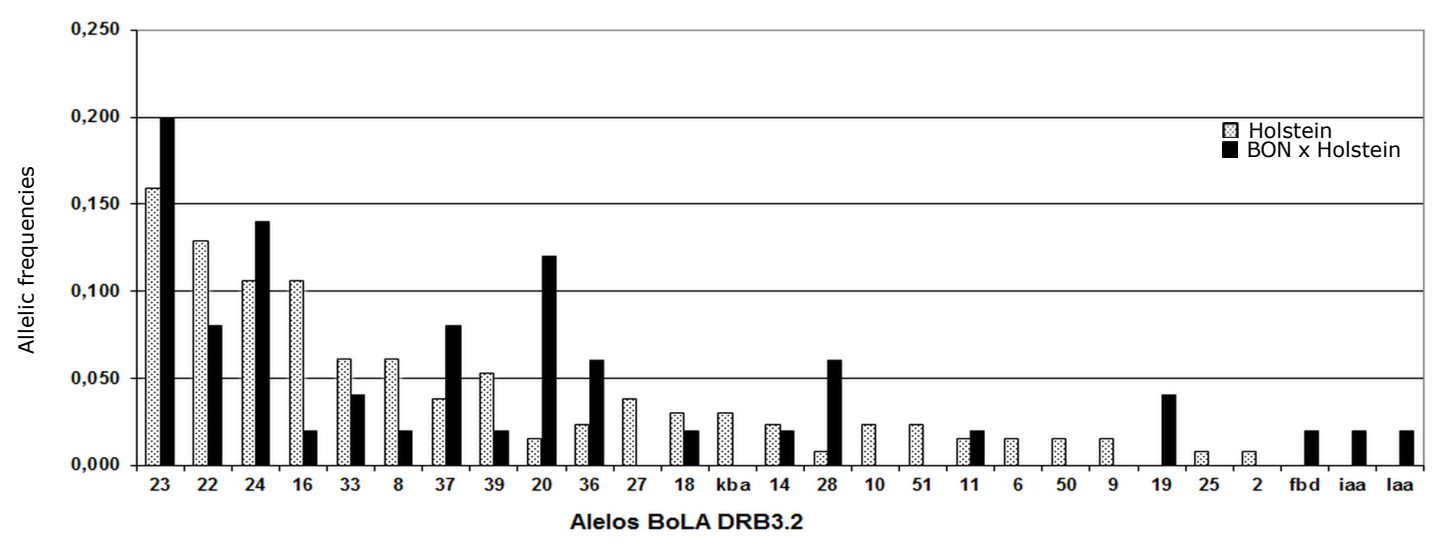

Figure 1. Allelic frequencies for gene BoLA DRB3.2 in two genetic groups, Holstein and BxH. 
Table 1. Mean and standard deviation for milk production and compositional quality traits in Holstein and BxH cows.

\begin{tabular}{lcccccccc}
\hline & \multicolumn{7}{c}{ Trait } \\
\cline { 2 - 9 } & $\mathbf{n}$ & $\begin{array}{c}\text { PL305 } \\
\mathbf{k g} \pm \mathbf{D E}\end{array}$ & $\mathbf{n}$ & $\begin{array}{c}\text { PP305 } \\
\mathbf{k g} \pm \mathbf{D E}\end{array}$ & $\begin{array}{c}\text { PPRO } \\
\mathbf{\%} \pm \mathbf{D E}\end{array}$ & $\mathbf{N}$ & $\begin{array}{c}\text { PG305 } \\
\mathbf{k g} \pm \mathbf{D E}\end{array}$ & $\begin{array}{c}\text { PGRA } \\
\% \pm \mathbf{D E}\end{array}$ \\
\hline Holstein primiparous & 243 & $5316 \pm 1229$ & 163 & $155 \pm 37$ & $3.02 \pm 0.44 \neq$ & 163 & $182 \pm 40$ & $3.56 \pm 0.44$ \\
Holstein multiparous & 200 & $6599 \pm 1298 \neq$ & 169 & $187 \pm 42 \neq$ & $2.87 \pm 0.35$ & 169 & $228 \pm 52 \neq$ & $3.50 \pm 0.53$ \\
Holstein & 443 & $5895 \pm 1366 \neq$ & 332 & $171 \pm 43 \neq$ & $2.94 \pm 0.35$ & 332 & $205 \pm 52 \neq$ & $3.53 \pm 0.49$ \\
BxH & 180 & $4045 \pm 853$ & 100 & $133 \pm 28$ & $3.23 \pm 0.21 \neq$ & 100 & $169 \pm 37$ & $4.11 \pm 0.48 \neq$ \\
Farm Paysandú & 623 & $5361 \pm 1496$ & 432 & $162 \pm 43$ & $3.01 \pm 0.35$ & 432 & $197 \pm 51$ & $3.66 \pm 0.54$ \\
\hline
\end{tabular}

PL305 = Milk yield adjusted to 305 days, PP305 = Protein yield adjusted to 305 days, PPRO = Protein Percentage, PG305=Fat yield adjusted to 305 days, PGRA $=$ Fat percentage, $\mathrm{n}=$ Number of records, $\mathrm{DE}=$ Standard Deviation, $* \mathrm{p} \leq 0.10,+\mathrm{p} \leq 0.05, \neq \mathrm{p} \leq 0.01$

genetic group was significant $(p \leq 0.01)$ for this characteristic, with a PP305 mean higher for Holstein $(171 \mathrm{~kg})$, than for $\mathrm{BxH}(133 \mathrm{~kg})$. Likewise, the effect of the number of calvings was significant $(p \leq 0.01)$; in the analysis done for Holstein cows; primiparous cows had a PP305 mean of $155 \mathrm{~kg}$, while multiparous cows had a mean of $187 \mathrm{~kg}$ (Table 1). The mean for PPRO in the assessed population was $3.01 \%$ and the mean for each genetic group was significantly different ( $p \leq 0.01)$; for $\mathrm{BxH}$ it was higher with $3.23 \%$ and for Holstein it was $2.94 \%$. Regarding the fixed effect of the number of calvings, it was significant for the Holstein breed $(p \leq 0.01)$, where primiparous cows presented a PPRO mean of $3.02 \%$ and multiparous were $2.87 \%$ (Table 1 ).

Fat Production and Percentage. PG305 for the assessed population was $197 \mathrm{~kg}$. The fixed effect of the genetic group was significant $(p \leq 0.01)$, with a mean of PG305 higher for the Holstein breed $(205 \mathrm{~kg})$, than for BxH (169 $\mathrm{kg}$ ). Likewise, the fixed effect of the number of calvings in Holstein cows was significant $(p \leq 0.01)$; primiparous cows had a PG305 mean of $182 \mathrm{~kg}$, while multiparous cows had a mean of $228 \mathrm{~kg}$ (Table 1). The mean for PGRA in the assessed population was $3.66 \%$ and the means for each genetic group were significantly different $(\mathrm{p} \leq 0.01)$; for $\mathrm{BxH}$ it was $4.11 \%$ and for Holstein it was $3.53 \%$ regarding calving effect, there were no significant differences found in Holstein, primiparous cows had a PPRO mean of $3.56 \%$ and multiparous cows had $3.50 \%$ (Table 1 ).

Association of BOLA DRB3.2 alleles with PL305, PP305 and PG305. Comparing the PL305 means of each BoLA DRB3.2 allele with the substitution allele (allele 24 ), a highly significant association in multiparous cows was found, with the decrease in PL305 from allele 36 with 1674 less than those cows carrying the substitution allele $(p \leq 0.01)$ (Table 2). A significant association was also found in Holstein cows with a rise in the PG305 for allele $36(p \leq 0.01)$ in primiparous cows. se determinó que el $79 \%$ de las vacas fueron heterocigóticas y el $21 \%$ homocigóticas, para $\mathrm{BxH}$ se obtuvo un resultado muy similar, $80 \%$ de heterocigóticos y $20 \%$ homocigóticos para el gen BoLA DRB3.2.

Producción de leche. El promedio de PL305 en la población evaluada fue de $5361 \mathrm{Kg}$ (Tabla 1). El grupo genético tuvo un efecto significativo ( $\mathrm{s} \leq 0.01)$, con una media de PL305 mayor para Holstein $(5895 \mathrm{~kg})$, que para $\mathrm{BxH}(4045 \mathrm{~kg})$. Igualmente, el efecto parto fue significativo $(p \leq 0.01)$; en Holstein las vacas primíparas presentaron una media para PL305 de $5316 \mathrm{~kg}$, mientras que en las multíparas la media fue de $6599 \mathrm{~kg}$ por lactancia (Tabla 1).

Producción de proteína y porcentaje de proteína. La media para PP305 fue $162 \mathrm{~kg}$. El efecto del grupo genético fue significativo $(p \leq 0.01)$ para esta característica, con una media de PP305 mayor para Holstein $(171 \mathrm{~kg})$, que para $\mathrm{BxH}(133 \mathrm{~kg})$. Igualmente, el efecto número de parto fue significativo $(p \leq 0.01)$; en el análisis realizado para vacas Holstein; las vacas primíparas tuvieron una media de PP305 de $155 \mathrm{~kg}$, mientras que las multíparas presentaron una media de $187 \mathrm{~kg}$ (Tabla 1). La media para PPRO en la población evaluada fue de $3.01 \%$ y la media para cada grupo genético fue significativamente diferente $(p \leq 0.01)$; para BxH fue mayor con $3.23 \%$ y para Holstein $2.94 \%$. En cuanto al efecto fijo del número de parto, en la raza Holstein fue significativo $(p \leq 0.01)$, las vacas primíparas presentaron una media de PPRO de $3.02 \%$ y las multíparas de $2.87 \%$ (Tabla 1 ).

Producción de grasa y porcentaje de grasa. La PG305 para la población evaluada fue de $197 \mathrm{~kg}$. El efecto fijo del grupo genético fue significativo $(p \leq 0.01)$, con una media de PG305 mayor para la raza Holstein $(205 \mathrm{~kg})$, que para $\mathrm{BxH}(169 \mathrm{~kg})$. Igualmente, el efecto fijo de número de parto en vacas Holstein fue significativo $(p \leq 0.01)$; las vacas primíparas tuvieron una media de 
Table 2. Statistical significance of the association of BoLA DRB3.2 alleles with milk productions and compositional quality traits in Holstein cows. ${ }^{1}$

\begin{tabular}{|c|c|c|c|c|c|c|}
\hline \multirow[b]{2}{*}{ Alelo } & \multirow[b]{2}{*}{ Fre } & \multicolumn{5}{|c|}{ Traits } \\
\hline & & $\begin{array}{l}\text { PL305 } \\
\text { kg士DE }\end{array}$ & $\begin{array}{l}\text { PP305 } \\
\text { kg士DE }\end{array}$ & $\begin{array}{l}\text { PPRO } \\
\% \pm D E\end{array}$ & $\begin{array}{l}\text { PG305 } \\
\text { kg士DE }\end{array}$ & $\begin{array}{c}\text { PGRA } \\
\% \pm D E\end{array}$ \\
\hline \multicolumn{7}{|c|}{ Primiparous - Holstein } \\
\hline 33 & 6.1 & $\begin{array}{c}148 \\
\pm 380\end{array}$ & $\begin{array}{l}-10 \\
\pm 10\end{array}$ & $\begin{array}{c}0.40 \\
\pm 0.07 *\end{array}$ & $-5 \pm 9$ & $\begin{array}{l}-0.25 \\
\pm 0.16\end{array}$ \\
\hline 36 & 2.3 & $\begin{array}{c}170 \\
\pm 640\end{array}$ & $\begin{array}{c}59 \\
\pm 12\end{array}$ & $\begin{array}{l}-0.05 \\
\pm 0.17\end{array}$ & $\begin{array}{c}98 \\
\pm 47 \neq\end{array}$ & $\begin{array}{c}0.35 \\
\pm 0.24\end{array}$ \\
\hline 24 & 10.6 & $\begin{array}{c}0 \\
\pm 242\end{array}$ & $\begin{array}{c}0 \\
\pm 13\end{array}$ & $\begin{array}{c}0 \\
\pm 0.19\end{array}$ & $\begin{array}{c}0 \\
\pm 9\end{array}$ & $\begin{array}{c}0 \\
\pm 0.07\end{array}$ \\
\hline \multicolumn{7}{|c|}{ Multiparous-Holstein } \\
\hline 8 & 6.1 & $\begin{array}{l}-448 \\
\pm 355\end{array}$ & $\begin{array}{c}-1 \\
\pm 14\end{array}$ & $\begin{array}{c}0.20 \\
\pm 0.05\end{array}$ & $\begin{array}{c}17 \\
\pm 23\end{array}$ & $\begin{array}{c}0.48 \\
\pm 0.16^{*}\end{array}$ \\
\hline 16 & 10.6 & $\begin{array}{c}-47 \\
\pm 387\end{array}$ & $\begin{array}{c}16 \\
\pm 12\end{array}$ & $\begin{array}{c}0.21 \\
\pm 0.06 *\end{array}$ & $\begin{array}{c}9 \\
\pm 12\end{array}$ & $\begin{array}{c}0.19 \\
\pm 0.19\end{array}$ \\
\hline 22 & 12.9 & $\begin{array}{l}-491 \\
\pm 201\end{array}$ & $\begin{array}{l}-3 \\
\pm 5\end{array}$ & $\begin{array}{c}0.16 \\
\pm 0.04\end{array}$ & $\begin{array}{c}12 \\
\pm 10\end{array}$ & $\begin{array}{c}0.45 \\
\pm 0.15^{*}\end{array}$ \\
\hline 36 & 2.3 & $\begin{array}{l}-1674 \\
\pm 372 \neq\end{array}$ & $\begin{array}{l}-34 \\
\pm 14\end{array}$ & $\begin{array}{c}0.13 \\
\pm 0.08\end{array}$ & $\begin{array}{l}-20 \\
\pm 24\end{array}$ & $\begin{array}{c}0.55 \\
\pm 0.18 \dagger\end{array}$ \\
\hline 24 & 10.6 & $\begin{array}{c}0 \\
\pm 283\end{array}$ & $\begin{array}{c}0 \\
\pm 8\end{array}$ & $\begin{array}{c}0 \\
\pm 0.05\end{array}$ & $\begin{array}{c}0 \\
\pm 11\end{array}$ & $\begin{array}{c}0 \\
\pm 0.06\end{array}$ \\
\hline
\end{tabular}

Fre $=$ Frequency; ${ }^{1}$ Allele 24 was fixed to zero to compare allelic substitution, PL305 = Milk yield adjusted to 305 days, PP305=Protein yield adjusted to 305 days, PPRO $=$ Protein Percentage, PG305 $=$ Fat yield adjusted to 305 days, PGRA $=$ Fat Percentage,$D E=$ Standard Deviation, ${ }^{*} p \leq 0.10,+p \leq 0.05, \neq p \leq 0.01$

No significant associations were determined for these characteristics in $\mathrm{BxH}$ cows.

Association of BoLA DRB3.2 alleles with PPRO and PGRA. Significant associations were determined in the Holstein breed with a rise in PPRO for allele 33 in primiparous cows $(p \leq 0.10)$ with $0.40 \%$ more than in cows bearing the substitution allele and for allele 16 in multiparous cows with $0.21 \%$ more than in cows bearing the substitution allele $(p \leq 0.10)$ (Table 2$)$. For PGRA, allele 36 was associated with a rise in the levels of this trait in multiparous cows ( $\leq 0.05)$, with $0.55 \%$ more than in cows that bear the substitution allele. Alleles 8 and 22 were likewise associated to a rise in PGRA in multiparous cows $(p \leq 0.10)$ (Table 2). For the BxH genetic group, just one significant association was found in allele 19 , with a rise in PGRA with $0.8 \%$ more than cows that bear allele $24(p \leq 0.05)$, (Table 3$)$.

Table 3. Statistical significance of the association of BoLA DRB3.2*19 allele with milk production and compositional quality traits in BXH cows ${ }^{1}$

\begin{tabular}{ccccccc}
\hline & & \multicolumn{5}{c}{ Traits } \\
\cline { 3 - 7 } Allele & Fre & kg \pm DE & kg \pm DE & \% $\pm D E$ & kg $\pm D E$ & $\% \pm D E$ \\
\hline 19 & 4 & $-746 \pm 138$ & $-17 \pm 4$ & $0.14 \pm 0.08$ & $1 \pm 7$ & $0,8 \pm 0.09 \dagger$ \\
24 & 8 & $0 \pm 216$ & $0 \pm 1$ & $0 \pm 0.08$ & $0 \pm 12$ & $0 \pm 0.19$ \\
\hline
\end{tabular}

Fre=Frequency; ${ }^{1}$ Allele 24 was fixed to zero to compare allelic substitution, PL305 = Milk yield adjusted to 305 days, PP305=Protein yield adjusted to 305 days, PPRO $=$ Protein Percentage, PG305 = Fat yield adjusted to 305 days, PGRA $=$ Fat Percentage,$D E=$ Standard Deviation, ${ }^{*} p \leq 0.10,+p \leq 0.05, \neq p \leq 0.01$.
PG305 de $182 \mathrm{~kg}$, mientras que las multíparas presentaron una media de $228 \mathrm{~kg}$ (Tabla 1 ). La media para PGRA en la población evaluada fue de $3.66 \%$ y las medias para cada grupo genético fue significativamente diferente $(\mathrm{p} \leq 0.01)$; para $\mathrm{BxH}$ fue de $4.11 \%$ y para Holstein fue de $3.53 \%$ y en cuanto al efecto parto, en Holstein no se encontró diferencias significativas, las vacas primíparas tuvieron una media de PPRO de $3.56 \%$ y las multíparas de $3.50 \%$ (Tabla 1 ).

\section{Asociación de los alelos BoLA DRB3.2 con PL305, PP305 y PG305. Comparando las medias de PL305 de cada alelo BoLA DRB3.2 con el alelo de sustitución (alelo 24), se encontró en el grupo de vacas multíparas de raza Holstein, una asociación altamente significativa con disminución en la PL305 del alelo 36, con 1674 kg menos que las vacas portadoras del alelo de sustitución $(\mathrm{p} \leq 0.01)$ (Tabla 2). En la raza Holstein, también se encontró una asociación significativa con aumento en la PG305 para el alelo $36(p \leq 0.01)$ en vacas primíparas. En el grupo de vacas $\mathrm{BxH}$ no se determinaron asociaciones significativas para estas características.}

Asociación de los alelos BoLA DRB3.2 con PPRO y PGRA. En la raza Holstein fueron determinadas asociaciones significativas con aumento en el PPRO para el alelo 33 en vacas primíparas $(p \leq 0.10)$ con $0.40 \%$ más que las vacas portadoras del alelo de sustitución y para el alelo 16 en vacas multíparas con $0.21 \%$ más que las vacas portadoras del alelo de sustitución $(p \leq 0.10)$ (Tabla 2). Para PGRA, el alelo 36 fue asociado con aumento en los niveles de esta característica en vacas multíparas $(p \leq 0.05)$, con $0.55 \%$ más que las vacas que llevan el alelo de sustitución. Los alelos 8 y 22 igualmente fueron asociados significativamente con aumento en el PGRA en vacas multíparas $(p \leq 0.10)$ (Tabla 2). Para el grupo genético $B x H$ se encontró sólo una asociación significativa en el alelo 19, con aumento en el PGRA con $0.8 \%$ más que las vacas que llevan el alelo $24(p \leq 0.05)$, (Tabla 3$)$.

\section{DISCUSIón}

Frecuencias alélicas del gen BoLA DRB3.2. En el hato Paysandú fueron identificados 27 alelos BoLA DRB3.2 en los grupos genéticos Holstein y $\mathrm{BxH}$, siendo indicativo de un alto polimorfismo para este gen. En el grupo genético Holstein se encontraron 23 alelos BoLA DRB3.2 y los 10 alelos más frecuentes fueron: BoLA DRB3.2*23, $22,24,16,33,8,39,37,27$ y 18 y presentaron una frecuencia acumulada de 0.78. Estos resultados fueron similares a los obtenidos por varios autores que determinaron las frecuencias 


\section{DISCUSSION}

Allelic frequencies of gene BoLA DRB3.2. 27 BoLA DRB3.2 alleles were identified at Paysandú cattle farm in genetic groups Holstein and $\mathrm{BxH}$, indicating a high polymorphism for this gene. The Holstein genetic group had 23 BoLA DRB3.2 alleles, and the 10 most frequent alleles were: BoLA DRB3.2*23, 22, 24, 16, 33, 8, 39, 37, 27 and 18 presenting an accumulated frequency of 0.78 . These results were similar to those obtained by various authors who determined the allele frequencies of the gene BoLA DRB3.2 in various Holstein populations and which Support the results of this investigation $(6,10,11,17-19)$.

On the other hand, 18 BoLA DRB3.2 alleles were identified for the $\mathrm{BxH}$ genetic group, out of which 11 were reported to be from the blanco Orejinegro (BON) breed, (20). The allelic frequencies obtained in $\mathrm{BxH}$ cows in this study were different, compared to those obtained from the BON breed (20). The differences in the allelic frequencies is possibly due to the fact that mainly $\mathrm{F}_{2}(25 \%$ BON and $75 \%$ Holstein) animals were used in this investigation. de los alelos del gen BoLA DRB3.2 en varias poblaciones de raza Holstein y que soportan los resultados de esta investigación $(6,10,11,17-19)$.

Por otra parte, para el grupo genético $\mathrm{BxH}$, se identificaron 18 alelos BoLA DRB3.2 de los cuales 11 fueron reportados en la raza blanco Orejinegro (BON), (20). Las frecuencias alélicas obtenidas en vacas $\mathrm{BxH}$ en este estudio fueron diferentes comparadas con las obtenidas en la raza BON (20). La diferencia en las frecuencias alélicas se debe posiblemente a que en esta investigación se emplearon principalmente animales $\mathrm{F}_{2}(25 \%$ BON y $75 \%$ Holstein).

Asociación de alelos BoLA DRB3.2 con características productivas. Han sido reportados varios alelos BoLA DRB3.2 asociados a características productivas; principalmente producción de leche, grasa y proteína $(6,10,12$, 21-23), (Tabla 4). En este estudio se encontraron asociaciones significativas de los alelos 8,16 y 22, que también fueron reportados por otros autores (Tabla 4). Sin embargo, algunas asociaciones de los alelos 19, 33 y 36 con características productivas determinadas en este estudio, no han sido reportadas por otros autores.

Table 4. Associations of BoLA DRB3.2 alleles with productive traits found in literature and in this investigation.

\begin{tabular}{|c|c|c|c|c|c|c|}
\hline \multirow{2}{*}{ Allele } & \multirow{2}{*}{ Breed } & \multirow{2}{*}{ No Animals } & \multicolumn{3}{|c|}{ Traits } & \multirow{2}{*}{ Reference } \\
\hline & & & Milk & Protein & Fat & \\
\hline 3 & Holstein & 186 & Decrease & & Decrease & 6 \\
\hline 6 & Gyr & 1058 & & Decrease & & 12 \\
\hline \multirow{3}{*}{7} & Holstein & 186 & Increase & Increase & & 6 \\
\hline & Gyr & 1058 & & Increase & & 12 \\
\hline & Holstein & 186 & Decrease & Decrease & Decrease & 6 \\
\hline \multirow{3}{*}{8} & Holstein & 835 & Increase & Increase & Increase & 10 \\
\hline & Holstein & 328 & Decrease & Increase & & 11 \\
\hline & Holstein ${ }^{1}$ & 66 & & & Increase ${ }^{*}$ & \\
\hline \multirow[t]{2}{*}{10} & Holstein & 328 & & & Increase & 6 \\
\hline & Holstein & 186 & Increase & Increase & Decrease & 6 \\
\hline \multirow[t]{3}{*}{11} & Holstein & 328 & Increase & Increase & Increase & 11 \\
\hline & Holstein & 262 & & & Increase ${ }^{*}$ & 22 \\
\hline & Gyr & 424 & Increase & & & 21 \\
\hline \multirow[t]{2}{*}{16} & Holstein & 328 & & & Decrease & 11 \\
\hline & Holstein ${ }^{1}$ & 66 & & Increase ${ }^{*}$ & & \\
\hline \multirow[t]{2}{*}{19} & BONxHolstein ${ }^{1}$ & 25 & & & Increase ${ }^{*}$ & \\
\hline & Holstein & 835 & Decrease & Decrease & & 10 \\
\hline \multirow[t]{2}{*}{22} & Holstein & 262 & & Increase $^{*}$ & Increase ${ }^{*}$ & 22 \\
\hline & Holstein ${ }^{1}$ & 66 & & & Increase ${ }^{*}$ & \\
\hline 23 & Holstein & 328 & Increase & Increase & & 11 \\
\hline \multirow{2}{*}{24} & Holstein & 186 & & & Increase & 6 \\
\hline & Holstein & 262 & & Increase $^{*}$ & & 22 \\
\hline 26 & Holstein & 186 & Decrease & Decrease & Decrease & 6 \\
\hline 27 & Holstein & 186 & Increase & & & 6 \\
\hline 29 & Gyr & 424 & Increase & & & 21 \\
\hline \multirow[t]{2}{*}{33} & Holstein ${ }^{1}$ & 65 & & Decrease $^{*}$ & & \\
\hline & Holstein ${ }^{1}$ & 66 & Decrease & & & \\
\hline \multirow[t]{2}{*}{36} & Holstein ${ }^{1}$ & 66 & & & Increase & \\
\hline & Holstein ${ }^{1}$ & 66 & & & Increase ${ }^{*}$ & \\
\hline 54 & Gyr & 1058 & & Decrease & Decrease & 12 \\
\hline
\end{tabular}

${ }^{1}$ BoLA DRB3.2 alleles associated to productive traits found in this investigation. ${ }^{*}$ The association is referenced as a percentage of the evaluated characteristic. 
Association of BoLA DRB3.2 alleles with production traits. Several BoLA DRB3.2 alleles were reported associated to production traits; mainly milk, fat and protein production $(6,10,12,21-23)$, (Table 4). Significant association found in this study were among alleles 8,16 and 22, which were also reported by other authors (Table 4). However, some associations from alleles 19, 33 and 36 with production trait determined in this study, have not been reported by other authors.

In this study, allele 8 was significantly associated to an increase in PGRA in multiparous cows of the Holstein genetic group. This result agrees with that reported by Sharif et al (10), who determined significant associations with an increase in fat production. However, those authors, also determined that allele 8 was associated to an increase in milk and protein production in Holstein cows, in contradiction to Starkenburg et al (6), who determined significant associations of allele 8 with a decrease in milk, fat and protein production in cows from the selection line of third lactation. Additionally, allele 8 was associated significantly to a decrease in protein and milk production during the third lactation period, in combined lines (control and selection). Rupp et al (11), likewise, determined significant associations of allele 8 with a decrease in milk production and an increase in protein production (Table 4).

Additionally, during this investigation, a significant association of allele 16 with increase in PPRO in multiparous Holstein cows, Rupp et al (11), determined a significant association of allele 16 with a decrease in the fat production in Holstein cow for the three first lactation periods and Machado et al (21), found for the same allele, a significant association with milk production in Gyr cows. This study found that allele 22 has a significant association with an increase in PGRA in multiparous cows of the Holstein genetic group, which agrees with the results obtained by Pashmi et al (22), who found an increase in fat percentage in Iranian Holstein. Sharif et al (10) did not find associations of allele 22 with fat production or percentage, but did determine significant associations of this allele with a decrease in milk and protein production in both previous and subsequent lactating groups (Table 4).

Allele 36 was another variant of gene BoLA DRB3.2 that was significantly associated with an increase in PG305 in primiparous cows $(p<0.01)$, with an increase in PGRA $(p<0.05)$ and with a decrease in PL305 in multiparous Holstein cows $(p<0.01)$. Another allele that presented
En este estudio el alelo 8 fue asociado significativamente con incremento en el PGRA en vacas multíparas del grupo genético Holstein, resultado que concuerda con el obtenido por Sharif et al (10), quienes determinaron asociaciones significativas con incremento en la producción grasa. Sin embargo, estos autores también determinaron que el alelo 8 estaba asociado con el incremento en la producción de leche y de proteína en vacas Holstein, pero contradictoriamente, Starkenburg et al (6) determinaron asociaciones significativas del alelo 8 con disminución en la producción de leche, grasa y proteína para vacas de la línea de selección de la tercera lactancia. Además, en líneas combinadas (de control y de selección), el alelo 8 fue asociado significativamente con disminución en la producción de proteína y leche durante la tercera lactancia. Rupp et al (11), igualmente determinaron asociaciones significativas del alelo 8 con disminución en producción de leche y con incremento en la producción de proteína (Tabla 4).

Adicionalmente en esta investigación se determinó una asociación significativa del alelo 16 con el incremento en el PPRO en vacas multíparas de raza Holstein. Rupp et al (11), encontraron una asociación significativa del alelo 16 con disminución en la producción de grasa en vacas Holstein para las tres primeras lactancias y Machado et al (21), encontraron para el mismo alelo una asociación significativa con producción de leche en vacas de raza Gyr. Para el alelo 22, se encontró en este estudio que fue asociado significativamente con aumento en el PGRA en vacas multíparas de del grupo genético Holstein, que concuerda con el resultado obtenido por Pashmi et al (22), quienes encontraron un incremento en el porcentaje de grasa en vacas Holstein Iraní. Sharif et al (10) no encontraron asociaciones del alelo 22 con producción de grasa ni porcentaje de grasa, pero sí determinaron asociaciones significativas de este alelo con disminución en la producción de leche y producción de proteína en los dos grupos de lactancias previas y subsecuentes (Tabla 4).

El alelo 36 fue otra variante del gen BoLA DRB3.2 que estuvo asociado significativamente con aumento en la PG305 en vacas primíparas $(p<0.01)$, con aumento en el PGRA $(p<0.05)$ y con disminución en la PL305 para vacas multíparas de raza Holstein $(p<0.01)$. Otro alelo que mostró asociaciones significativas en vacas $\mathrm{BxH}$ fue el alelo 19 (ausente en la raza Holstein), en este caso se encontró que está asociado significativamente con aumento en el PGRA. De estos dos alelos no han sido reportadas asociaciones con características productivas, ni enfermedades infecciosas. 
significant associations in $\mathrm{BxH}$ cows, was allele 19 (absent in Holstein), in this case, it was found to be significantly associated to an increase in PGRA. Associations to productive characteristics or infectious diseases have not yet been reported for these two alleles.

In results obtained by other authors, and compared with those found in this investigation, only one discrepancy was found for allele 8, which was associated with an increase in fat percentage during this study, and which Starkenburg et al (6), determined that was associated with a decrease on fat production. Likewise, there were contradictions between the results obtained by other authors, such as Sharif et al (10) who found that allele 8 was associated to an increase in milk, fat and protein production, while Starkenburg et al (6) found associations of allele 8 with a decrease in milk, fat and protein production. Rupp et al (11), reported associations of allele 8 with a decrease in the production of milk and an increase in the production of protein.

Sharif et al (10), establishes that these inconsistencies may be due to the different states of linkage disequilibrium between populations and that it is also necessary to apply higher statistical astringency to exclude the possibility of presence of erroneous associations, caused by multiple comparison samples. Other factors that may be involved in the inconsistencies among results obtained by different authors, may possibly be the Genotype-Environment interaction, given that the investigations are undertaken in different parts of the world. However, to obtain more precise results, the use of populations with high number of individuals is required, given that the elevated number of polymorphism of gene DRB3, leads to the gaining of low allelic and genotype frequencies.

Rupp et al (11), considers that these differences have been notoriously difficult to avoid and are one of the strong impediment for a selection based on the breeding value in the $\mathrm{CMH}$ genotype. However, he explains, by quoting Alizadeh et al (23) that this cannot conclude that the information in the expression of $\mathrm{CMH}$ genes, does not improve the mechanisms involved in the resistance to diseases or that it is not one of the many tools that may be used to improve animal health and indirectly productivity in these particular populations.

Gene BoLA DRB3 has been associated to resistance and susceptibility to infectious diseases and its main function is the expression of antigen-presenting proteins (7). However, it is also associated to productive traits. Although the
En resultados obtenidos por otros autores, y comparados con los encontrados en esta investigación, solo se encontró una discrepancia para el alelo 8, que en este estudio fue asociado con incremento en el porcentaje de grasa y Starkenburg et al (6), determinaron que fue asociado con disminución en la producción de grasa. Igualmente, hubo contradicciones entre los resultados obtenidos por otros autores, por ejemplo, Sharif et al (10) encontraron que el alelo 8 fue asociado con incremento de la producción de leche, grasa y proteína, mientras que Starkenburg et al (6) encontraron asociaciones del alelo 8 con disminución en la producción de leche, grasa y proteína. Rupp et al (11), reportaron asociaciones del alelo 8 con disminución en la producción de leche y con incremento en la producción de proteína.

Sharif et al (10), establecen que estas inconsistencias pueden ser debido a los diferentes estados de desequilibrio de ligamiento entre poblaciones y que además es necesario aplicar mayor astringencia estadística para excluir la posibilidad de la presencia de asociaciones erróneas, causadas por las pruebas de comparación múltiple. Otros factores que pueden estar involucrados en las inconsistencias entre los resultados obtenidos por los autores mencionados anteriormente, puede ser posiblemente la interacción genotipo ambiente, dado que las investigaciones son realizadas en diferentes partes del mundo. Sin embargo, para obtener resultados más precisos, se requiere de utilizar poblaciones con alto número de individuos, dado que el elevado polimorfismo del gen DRB3, que conlleva a obtener frecuencias alélicas y genotípicas bajas.

Rupp et al (11), consideran que estas discrepancias han sido notoriamente difíciles de evitar y son uno de los fuertes impedimentos para realizar una selección basada en valor de cría en el genotipo CMH. Sin embargo, explica, citando a Alizadeh et al (23) que no se puede concluir que la información de la expresión de los genes del $\mathrm{CMH}$ no mejora los mecanismos involucrados en la resistencia a enfermedades o que no es una de las muchas herramientas que puede ser usada para mejorar la salud animal e indirectamente la productividad de estos en poblaciones particulares.

El gen BoLA DRB3 ha sido asociado con resistencia y susceptibilidad a enfermedades infecciosas y su función principal es la expresión de proteínas presentadoras de antígeno (7). Sin embargo, también muestra estar asociado con características productivas. No obstante, la relación entre el gen BoLA con estas características 
relationship between the gene BoLA with these characteristics is not direct, given that $\mathrm{CMH}$ genes are not involved in the process of milk secretion. The relationship is given when finding animal with allele variants that allow them to be resistant to infectious diseases, and this resistance must be reflected by an increase in productivity, or that very productive animals present allelic variants with susceptibility to infectious diseases $(11,24)$.

This investigation found that allele 8 was associated to an increase in the fat percentage in multiparous Holstein cows $(p \leq 0.1)$. However, other investigations report that it was associated to susceptibility to subclinical mastitis $(6,22,25)$. Likewise, this investigation determined that allele 33 was significantly associated to the decrease in protein percentage in Holstein primiparous cows ( $p \leq 0.1)$, and it was also reported that allele 33 is associated to resistance of subclinical mastitis (25). Even though some alleles have been associated to production and mastitis, it is clear that alleles from gene BoLA DRB3.2 have not yet been reported, to present concluding superiority for productive traits and resistance to infectious diseases. However, the results obtained in this investigation and in those of other authors, generate great interest in finding genes associated to sanity and production, or even other economically important traits, to be included in molecular marker assisted selection programs.

\section{Acknowledgements}

This article was part of the project: Correlation between clinical and subclinical mastitis with the genotypic variants of gene BoLA DRB3.2, present in cows and calves of first calving at the milk farm of hacienda Paysandú at the Universidad Nacional de Colombia, QUIPU code 20101006713, financed by the Dirección de Investigación de la Universidad Nacional de Colombia sede Medellín. no es directa, dado que los genes del $\mathrm{CMH}$ no están involucrados en el proceso de secreción de leche. La relación se da al encontrar animales con variantes alélicas que les permite ser resistentes a enfermedades infecciosas y esta resistencia debe ser reflejada en un aumento en la productividad, o que animales muy productivos presenten variantes alélicas asociadas con susceptibilidad a enfermedades infecciosas $(11,24)$.

En esta investigación se encontró que el alelo 8 fue asociado con incremento en el porcentaje de grasa en vacas multíparas de raza Holstein ( $p \leq$ 0.1 ). Sin embargo, en otras investigaciones se reporta que fue asociado con susceptibilidad a mastitis subclínica $(6,22,25)$. De igual manera, se determinó en esta investigación que el alelo 33 fue asociado significativamente con disminución en el porcentaje de proteína en vacas primíparas de raza Holstein $(p \leq 0.1)$, y también se ha reportado que el alelo 33 ha sido asociado con resistencia a mastitis subclínica (25). Si bien, algunos alelos han sido asociados con producción y mastitis, es claro que aún no han sido reportados alelos del gen BoLA DRB3.2, que presenten superioridad contundente para características productivas y resistencia a enfermedades infecciosas. No obstante, los resultados obtenidos en esta investigación y en las de otros autores, generan gran interés por encontrar genes asociados a sanidad y producción, e incluso de otras características de importancia económica, para ser incluidos en programas de selección asistida por marcadores moleculares.

\section{Agradecimientos}

Este artículo fue parte del proyecto: Correlación entre mastitis clínica y subclínica con las variantes genotípicas del gen BoLA DRB3.2, presentes en las vacas y novillas de primer parto del hato lechero de la hacienda Paysandú de la Universidad Nacional de Colombia, código QUIPU 20101006713, financiado por la Dirección de Investigación de la Universidad Nacional de Colombia sede Medellín. 


\section{REFERENCES}

1. Espinal CF, Martínez HJ, González FA. La cadena de lácteos en Colombia: una mirada global de su estructura y dinámica 1991-2005. [En Línea]. 2005 (fecha de acceso 20 abril de 2011); (74). URL disponible en: http://www.agronet.gov. co/www/docs_agronet/2005112162250_ caracterizacion_lacteos.pdf

2. Fedegan. Estadísticas: Producción Colombia. [En Linea]. 2013. (Fecha de acceso 8 de diciembre de 2013). URL disponible en: http://www.fedegan.org.co/estadisticas/ produccion-0

3. Oltenacu PA, Broom DM. The Impact of genetic selection for increased milk yield on the welfare of dairy cows. Animal Welf 2010; 19(S):39-49

4. Carlén E, Strandberg E, Roth A. Genetic parameters for clinical mastitis, somatic cell score, and production in the first three lactations of Swedish Holstein cows. J Dairy Sci 2004; 87:3062-3070.

5. Quintero GE. Evolución y desarrollo del sector Lácteo en Colombia desde la perspectiva del eslabón primario (Producción). Medellín Colombia: Corporación Universitaria La Sallista, Facultad de Ciencias Administrativas y Agropecuarias. Posgrado en Especialización en Gerencia Agropecuaria: 2011.

6. Starkenburg RJ, Hansen LB, Kehrli JR, ChesterJones $\mathrm{H}$. Frequencies and effects of alternative DRB3.2 alleles of bovine lymphocyte antigen for Holstein in milk selection and control lines. J Dairy Sci 1997; 80:3411-3419.

7. Behl JD, Verma NK, Tyagi N, Mishra P, Behl R, Joshi BK. The major histocompatibility complex in bovines: A Review. ISRN Veterinary Science 2012; 2012:1-12

8. Wang $K$, Sun $D$, Zhang $Y$. Sequencing of 15 new BoLA-DRB3 Alleles. Int J Immunogenet 2008; 35:331-332.

9. Lee BY, Hur TY, Jung YH, Kem H. Short Communication. Identification of BoLA DRB3.2 alleles in Korean native cattle (Hanwoo) and Holstein populations using a next Generation sequencer. Anim Genet 2012; 43(4):438-441.
10. Sharif S, Mallard BA, Wilkie BN, Sargeant JM, Scott HM, Dekkers JC et al. Associations of the bovine major histocompatibility complex DRB3 (BoLA-DRB3) alleles with production traits in Canadian dairy cattle. Anim Genet 1998; 30:157-160.

11. Rupp R, Hernandez A, Mallard BA. Association of bovine leukocyte antigen (BoLA) DRB3.2 with immune response, mastitis and production and type traits in Canadian Holsteins. J Dairy Sci 2007; 90:1029-1038.

12. Nascimento CS, Machado MA, Martínez ML, Barbosa MV, Martins MF, Campos AL, et al. Association of the bovine major histocompatibility complex (BoLA) BoLADRB3 gen with fat and protein production and somatic cell score in Brazilian Gyr Dairy cattle (Bos indicus). Genet Mol Biol 2006; 29(4):641-647.

13. Wojdak-Maksymiec K, Kmiec M, KowalewskaLuczac I, Warliñski M. DRB3 Gene polymorphism and somatic cell count in milk of jersey. J Anim Vet Adv 2010; 9(9):12951300.

14. Van Eijk MJT, Stewart-Haynes JA, Lewin HA. Extensive polymorphism of the BoLA-DRB3 gene distinguished by PCR-RFLP. Anim Genet 1992; 23:483.

15. Laird NM, Lange C. The Fundamentals of Modern Statistical Genétics. New York USA: Springer; 2011.

16. SAS/STAT: [Programa de ordenador] Version 9.1, Cary (NC): SAS Institue Incorporation; 2006.

17. Nassiry MR, Shahroodi EF, Mosafer J, Mohammadi A, Manshad E et al. Analysis and frequency of bovine lymphocyte antigen (BoLA DRB3) alleles in Iranian Holstein Cattle. Russ J Genet 2005; 41(6):664-668.

18. Nassiry MR, Sadeghi B, Tohidi R, Afshari JT, Khosravi M. Comparison of bovine lymphocyte antigen DRB3.2 allele frequencies between two subpopulations of Iranian Holstein cattle. Afr J Biotechnol 2008; 7(15):2671-2675.

19. Operzadek J, Urtnowski P, Sender G, Pawlik A, Lukaszewicz. Frequency of alleles BoLA-DRB3 in Polish Holstein-Friesian cattle. Anim Sci Pap Rep 2012; 30(2):91-101. 
20. Martínez R, Toro R, Montoya F, Burbano M, Tobón J, Gallego J y Ariza F. Caracterización del locus BoLA-DRB3 en ganado criollo colombiano y asociación con resistencia a enfermedades. Arch Zoot 2005; 54:(206207):350-356.

21. Machado MA, Nascimento CS, Martinez ML, Silva GB, Campos AL, Teodoro RL et al. Association of BoLA-DRB3.2 locus with bovine milk production in Gyr breed. Arq Bras Med Vet Zootec 2005; 57(3):380-389.

22. Pashmi M, Qanbari S, Ghorashi SA, Sharifi AR. Analysis of relationship between bovine lymphocyte antigen DRB3. 2 alleles, somatic cell count and milk traits in Iranian Holstein population. J Anim Breed Genet 2009; 126:296-303
23. Alizadeh Z, Karrow N, Mallard BA. Biological effect of varying peptide binding affinity to the BoLA-DRB3*2703 allele. Genet Sel Evol 2003; 35(1):51-65.

24. Rupp R, Boichard D. Genetics of resistance to mastitis in dairy cattle. Vet Res $2003 ; 34: 671-$ 688.

25. Zambrano JC, López-Herrera A, Echeverri JJ. Alleles of the BoLA DRB3.2 gene are associated with mastitis in dairy cows. Rev Col Cienc Pec 2011; 24(2):145-156. 